Vol. 15 (2006): 124-137.

\title{
Spring barley yield and nitrogen recovery after application of peat manure and pig slurry
}

\author{
Pasi K. Mattila \\ Department of Applied Chemistry and Microbiology, PO Box 27, FI-00014 University of Helsinki, Finland, \\ e-mail: pasi.mattila@helsinki.fi
}

\begin{abstract}
The effectiveness of peat manure, manufactured of pig slurry and moderately humified Sphagnum peat (slurry:peat ca. 1:1.5 v/v), as nitrogen $(\mathrm{N})$ source for spring barley was investigated in a four-year field experiment on a clay loam soil in south-western Finland. Pig slurry, NPK fertilizer and plain peat were used as references. Manures were incorporated before sowing or surface-applied after sowing in spring at an ammoniacal $\mathrm{N}$ rate of 54-106 $\mathrm{kg} \mathrm{ha}^{-1}$ with or without supplementary NPK fertilizer $\left(40 \mathrm{~kg} \mathrm{~N} \mathrm{ha}^{-1}\right)$. Soil moisture conditions were varied by different irrigation treatments. Peat manure produced 5-15\% higher grain yields than pig slurry, with the largest difference after surface application. Incorporation was more important for slurry than for peat manure in increasing $\mathrm{N}$ uptake and yield. Soil moisture deficit in spring and early summer limited the availability of manure $\mathrm{N}$. Part of the manure $\mathrm{N}$ that was not available in the early growing period was apparently taken up by the crop later. Consequently, $\mathrm{N}$ concentration tended to be higher with lower yields, and differences in the recovery of manure $\mathrm{N}$ were smaller than the differences in grain yield. Supplementation of manures with inorganic fertilizer $\mathrm{N}$ increased yield by $37 \%$, on average, and improved the $\mathrm{N}$ recovery.
\end{abstract}

Key words: nitrogen, manures, slurries, peat, barley

\section{Introduction}

A major portion of manure nitrogen $(\mathrm{N})$ is lost to the environment, with negative impacts (van der Hoek 1998, Galloway et al. 1998). Transport and application costs often make manure a more expensive source of nutrients than commercial fertilizer (Araji et al. 2001) and application methods that abate emissions, for example by reducing the volatilization of ammonia $\left(\mathrm{NH}_{3}\right)$, increase costs (Huijsmans et al. 2004). However, our need to protect the environment requires proper manure management and recycling of manure $\mathrm{N}$.

In areas of Finland where peat is easily available, it has traditionally been used as a bedding material for domestic animals. In the late 1980s the Finnish company Vapo Oy developed a machine to 
Vol. 15 (2006): 124-137.

mix manure slurry and other effluents with peat (Fig. 1). Some units have been in use on farms. The most suitable type of peat for manure treatment is moderately humified Sphagnum peat. Its high cation exchange capacity (Puustjärvi 1956) enables it to adsorb ammonium in a plant-available form limiting thus $\mathrm{N}$ losses through the volatilization of ammonia $\left(\mathrm{NH}_{3}\right)$. Sphagnum peat can adsorb $2.3 \% \mathrm{NH}_{3}$ per dry matter (Kemppainen 1987) and it also has a high water absorption capacity (Puustjärvi 1976).

The absorption of slurry into peat converts the slurry into solid peat manure, which can be stored in heaps. The method is especially useful on farms where the storage capacity for slurry is not sufficient for the whole amount of slurry accumulated during winter. Mixing the surplus slurry with peat reduces the need to spread slurry in autumn. Postponement of manure application until spring may raise the utilization of manure $\mathrm{N}$ by crops several times higher (Kemppainen 1989) and prevents leaching losses of manure $\mathrm{N}$ that may occur in winter and during snowmelt (Kemppainen 1995, Turtola and Kemppainen 1998).

Manure spreading and incorporation into the soil before sowing in spring is often a problem because of wet soil and the shortage of time. After sowing there is more time for manure application and the soil is usually drier, but incorporation of surface applied manure with tillage implements is not possible, which makes manure $\mathrm{N}$ less available to plants and susceptible to losses through $\mathrm{NH}_{3}$ volatilization (van der Hoek 1998). Peat can reduce $\mathrm{NH}_{3}$ loss by adsorbing ammonium and, thus, peat manure is potentially more suitable for surface application than slurry. Surface applied peat may also reduce water evaporation by forming a cover on the soil (Russel 1939).

Supplementing manure with mineral fertilizer $\mathrm{N}$ has proven beneficial (Kemppainen 1989, p. 212-213, Petersen 1996). Fertilizer N helps to supply plants with adequate plant-available $\mathrm{N}$ especially in early developmental stages when the availability of manure $\mathrm{N}$ may be low because of low soil moisture content or initial immobilization of manure $\mathrm{N}$ into soil microbial biomass (Sørensen and Amato 2002). Another goal of N supplementation is to balance the amounts of applied nutrients with the nutrient requirements of crops and soil. The ratio of manure $\mathrm{N}$ to manure phosphorus is often lower than crop demand, which makes it reasonable to supplement manure with fertilizer $\mathrm{N}$ instead of applying manure at high rates and delivering excessive amounts of phosphorus.

The purpose of this study was to examine the effectiveness of peat manure as $\mathrm{N}$ source for spring barley. The main aim was to find out, whether peat manure has some advantages or disadvantages over slurry. The effects of postponing application after sowing, supplementary inorganic fertilizer N, and varying moisture conditions on barley yield and the utilization of manure $\mathrm{N}$ were of particular interest.

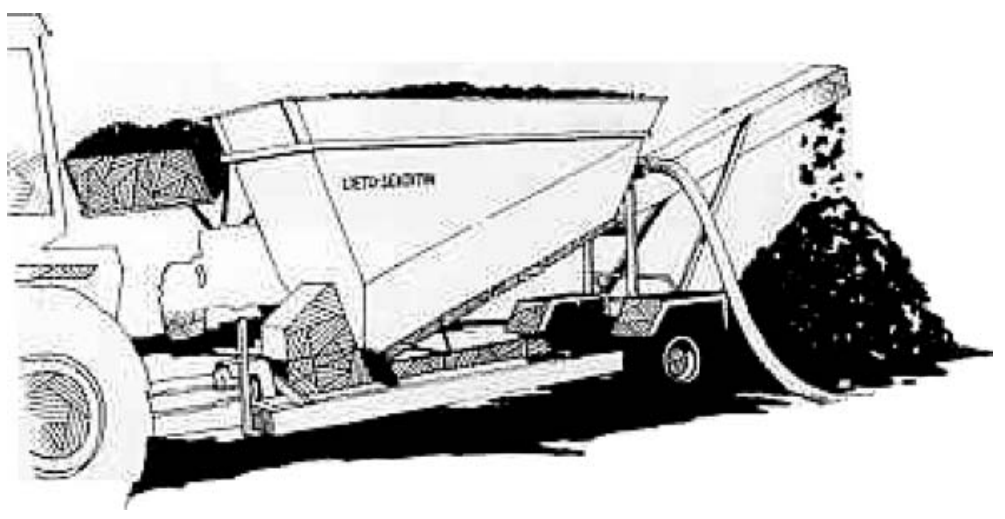

Fig. 1. Tractor-powered machine Lietu, which is manufactured by the Finnish company Vapo Oy for mixing slurry with peat. Slurry is led to the machine through a hose and peat is added with a front loader. The prepared peat manure falls from the end of mixing screws into a heap. (Figure: Vapo Oy) 


\section{Material and methods}

\section{Experimental site and treatments}

The experiment was carried out at MTT Agrifood Research Finland in Jokioinen (6049'N, 2328' E) on a clay loam soil (Table 1) in 1990-1994. According to FAO classification, the soil was a Vertic Cambisol (Alakukku and Elonen 1995). Weather data (Fig. 2) was obtained from a meteorological station located about $2 \mathrm{~km}$ from the experimental field.

The crop was spring barley (Hordeum vulgare L. var. Kustaa). Manures and fertilizers used in the experiment contained enough phosphorus and potassium to satisfy the nutrient requirements of barley at the experimental site (Table 1). Thus, it was assumed that the response to the treatments depended primarily on their effect on the availability of $\mathrm{N}$ and water for the barley crop.

The complete-block experiment was done with four replications. The following irrigation treatments were assigned to the four main plots of each replication: 1) no irrigation, 2) irrigation before sprouting (2-5 days after sowing of barley and subsequent surface application of manures), 3) irrigation at normal time (2-4 weeks after sowing) and 4) irrigation both before sprouting and at normal time.

Table 1. Soil properties of the experimental site at $0-20 \mathrm{~cm}$ and $20-40 \mathrm{~cm}$ depth, and average application rates of phosphorus, potassium, calcium and magnesium in manures.

\begin{tabular}{|c|c|c|c|c|c|}
\hline & \multicolumn{3}{|c|}{ Soil properties } & \multicolumn{2}{|c|}{ Application rate in manures, $\mathrm{kg} \mathrm{ha}^{-1} \mathrm{a}^{-1}$} \\
\hline & & $20 \mathrm{~cm}$ & $20-40 \mathrm{~cm}$ & Slurry & Peat manure \\
\hline Organic matter, $\%$ & 5.3 & & 2.8 & & \\
\hline $\mathrm{pH}$ & 6.7 & & 6.9 & & \\
\hline Phosphorus, $\mathrm{mg} \mathrm{l}^{-1} 1$ ) & 53.0 & high & 16.1 high & 19 & 23 \\
\hline Potassium, $\mathrm{mg} \mathrm{l}^{-1} 1_{1}$ & 236 & satisfactory & 208 satisfactory & 36 & 47 \\
\hline Calcium, mg $\mathrm{l}^{-11)}$ & 2920 & good & good & 20 & 34 \\
\hline Magnesium, $\mathrm{mg} \mathrm{l}^{-11)}$ & 371 & satisfactory & high & 6 & 15 \\
\hline
\end{tabular}

${ }^{1)}$ Extracted with acid ammonium acetate $\left(0.5 \mathrm{M} \mathrm{CH}_{3} \mathrm{COONH}_{4}, 0.5 \mathrm{M} \mathrm{CH}_{3} \mathrm{COOH}, \mathrm{pH} 4.65\right)$. Soil:extractant $=1: 10 \mathrm{v} / \mathrm{v}$. Classification according to the Finnish advisory soil analysis.

Fig. 2. Monthly average temperature and precipitation at Jokioinen (FMI 1991-1994, Drebs et al. 2002).

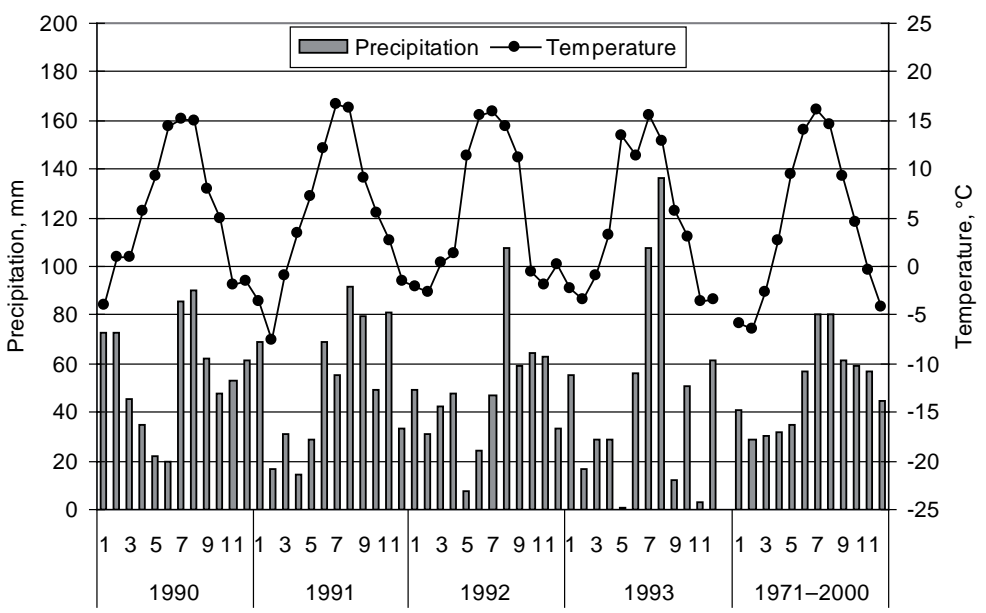


Vol. 15 (2006): 124-137.

Fertilizer treatments, which were laid as strips over the four main plots of each replication, were 1) pig slurry, 2) peat manure made by mixing pig slurry and Sphagnum peat, 3) Sphagnum peat (in 1990 and 1991 only), and 4) inorganic NPK fertilizer (NPK 20-4-8) which contained $\mathrm{N}$ as ammonium and nitrate. NPK strip was divided into four subplots within each main plot according to $\mathrm{N}$ level: 0 (unfertilized), 40, 80 and $120 \mathrm{~kg} \mathrm{~N} \mathrm{ha}^{-1}$.

Slurry, peat manure and peat were applied with two methods: 1) incorporation by harrowing to $5 \mathrm{~cm}$ depth before sowing or 2) surface application after sowing without incorporation, and were either 1) supplemented with $40 \mathrm{~kg} \mathrm{ha}^{-1}$ inorganic fertilizer N (NPK 20-4-8) or 2) left without supplementation. Each strip amended with slurry was divided into two substrips to which the two application methods were assigned. Each substrip was divided in two parts within each main plot to assign the two levels of supplementary fertilization ( $\mathrm{N} 0$ or $40 \mathrm{~kg} \mathrm{ha}^{-1}$ ). Peat manure or peat strips were divided in two parts within each main plot for the two application methods, whereas the two levels of supplementary fertilization were assigned to two substrips similar to those used for application methods in slurry strips. The arrangement was different for slurry and peat manure or peat because of different equipment used for application. With all experimental factors taken into account, the size of each homogeneously treated plot was $2 \mathrm{~m} \times$ $8 \mathrm{~m}$. Treatments applied to any single plot were the same throughout the experiment.

\section{Manures}

Pig slurry was obtained from a nearby commercial pig-fattening farm. Peat manure was prepared each year five to six months before spreading with the Lietu machine (Fig. 1) by mixing slurry with moderately humified Sphagnum peat (slurry:peat ca. $1: 1.5 \mathrm{v} / \mathrm{v})$. Peat manure was stored outdoors on a concrete surface in a heap covered with straw and plastic sheeting.

Concentrations of total $\mathrm{N}$ (Kjeldahl N), ammoniacal $\mathrm{N}\left(\mathrm{NH}_{3}-\mathrm{N}+\mathrm{NH}_{4}{ }^{+}-\mathrm{N}\right)$ and dry matter and $\mathrm{pH}$ were determined in slurry, peat manure and peat by the methods described by Kemppainen (1989, p. 176) (Table 2). For the analysis of ammoniacal $\mathrm{N}, 100 \mathrm{~g}$ of a slurry sample was extracted with 50 $\mathrm{ml} 2 \mathrm{M} \mathrm{HCl}+50 \mathrm{ml} 2.5 \mathrm{M} \mathrm{CaCl}_{2}$, whereas $50 \mathrm{~g}$ of a peat manure sample was extracted with $25 \mathrm{ml}$ $2 \mathrm{M} \mathrm{HCl}+25 \mathrm{ml} 2.5 \mathrm{M} \mathrm{CaCl}_{2}+150 \mathrm{ml}$ water. Concentration of $\mathrm{NH}_{4}^{+}$in the extracts was determined by distilling $20 \mathrm{ml}$ of each extract with $\mathrm{MgO}$ with consequent titration of the distillate with $0.1 \mathrm{M}$ $\mathrm{HCl}$.

\section{Management of the experiment}

The experimental field was harrowed two to three times in May. Amendments that were to be incorporated into the soil were then applied and incorporated by harrowing on the same day (except in 1991 and 1992, when peat manure was applied in the afternoon and incorporated the next morning). Barley was sown with $12.5-\mathrm{cm}$ row spacing at 5-cm depth with a combined fertilizer and seed drill. Barley seed was disinfected against fungal diseases. In NPK plots and supplementary fertilization plots, NPK fertilizer was simultaneously placed with $25-\mathrm{cm}$ row spacing at $8-\mathrm{cm}$ depth. The field was rolled, and surface applications of slurry, peat manure and peat were applied. The experiment was established during two to five days.

Slurry was applied to the soil surface with a slurry spreader equipped with injection tines which in this study were fitted with splash plates and kept above the soil to simulate broadcast spreading. The spreader was weighed before and after applications to determine the rate of application of the slurry. Peat and peat manure were weighed with a balance and spread manually with shovels and rakes, except in the first year a tractor driven manure spreader was used. Use of the spreader was abandoned in later years because the manure was distributed unevenly and had to be levelled manually with shovels and rakes.

Irrigations were carried out according to the experimental plan, except in 1991 when both irrigations were delayed one month because of rainy weather. The amount of water applied in each irrigation was $25-34 \mathrm{~mm}$. 
Mattila, P.K. Barley yield and $N$ recovery from manures

Table 2. Concentration and application rate of ammoniacal $\mathrm{N}$, total $\mathrm{N}$ and dry matter, and $\mathrm{pH}$ of pig slurry, peat manure and peat. Results are averages of two subsamples taken at application in the field, except for the newly mixed peat manure which was sampled 5-6 months earlier.

\begin{tabular}{|c|c|c|c|c|c|c|c|c|c|}
\hline \multirow[t]{2}{*}{ Year } & \multirow[t]{2}{*}{ Manure } & \multirow[t]{2}{*}{ Phase of sampling } & \multicolumn{2}{|c|}{ Ammoniacal N } & \multicolumn{2}{|c|}{ Total N } & \multicolumn{2}{|c|}{ Dry matter } & \multirow[t]{2}{*}{$\mathrm{pH}$} \\
\hline & & & $\mathrm{g} \mathrm{kg}^{-1}$ & $\mathrm{~kg} \mathrm{ha}^{-1}$ & $\mathrm{~g} \mathrm{~kg}^{-1}$ & $\mathrm{~kg} \mathrm{ha}^{-1}$ & $\mathrm{~g} \mathrm{~kg}^{-1}$ & $\mathrm{Mg} \mathrm{ha}^{-1}$ & \\
\hline \multirow[t]{7}{*}{1990} & \multirow[t]{2}{*}{ Slurry } & Incorporation & 4.0 & 83 & 5.6 & 115 & 98 & 2.0 & 7.3 \\
\hline & & Surface application & 3.7 & 71 & 5.3 & 100 & 73 & 1.4 & 7.6 \\
\hline & \multirow[t]{3}{*}{ Peat manure } & Newly mixed & 2.0 & - & 3.5 & - & 154 & - & 7.2 \\
\hline & & Incorporation & 2.0 & 81 & 3.4 & 137 & 135 & 5.4 & 6.8 \\
\hline & & Surface application & 2.1 & 86 & 3.5 & 147 & 151 & 6.3 & 6.3 \\
\hline & \multirow[t]{2}{*}{ Peat } & Incorporation & 0.16 & 6 & 1.2 & 41 & 166 & 6.0 & 3.4 \\
\hline & & Surface application & 0.14 & 5 & 1.3 & 44 & 175 & 6.2 & 3.3 \\
\hline \multirow[t]{7}{*}{1991} & \multirow[t]{2}{*}{ Slurry } & Incorporation & 5.1 & 100 & 7.3 & 142 & 81 & 1.6 & 7.5 \\
\hline & & Surface application & 5.1 & 92 & 7.3 & 131 & 81 & 1.5 & 7.5 \\
\hline & \multirow[t]{3}{*}{ Peat manure } & Newly mixed & 2.6 & - & 4.1 & - & 152 & - & 5.7 \\
\hline & & Incorporation & 2.4 & 85 & 4.5 & 158 & 179 & 6.3 & 7.5 \\
\hline & & Surface application & 2.5 & 86 & 5.5 & 194 & 187 & 6.6 & 7.4 \\
\hline & \multirow[t]{2}{*}{ Peat } & Incorporation & 0.20 & 2 & 4.1 & 36 & 531 & 4.7 & 3.0 \\
\hline & & Surface application & 0.07 & 1 & 4.0 & 36 & 529 & 4.7 & 3.1 \\
\hline \multirow[t]{5}{*}{1992} & \multirow[t]{2}{*}{ Slurry } & Incorporation & 3.4 & 68 & 4.1 & 82 & 15 & 0.3 & 7.8 \\
\hline & & Surface application & 3.4 & 106 & 4.1 & 127 & 16 & 0.5 & 7.8 \\
\hline & \multirow[t]{3}{*}{ Peat manure } & Newly mixed & 2.2 & - & 3.4 & - & 124 & - & 5.3 \\
\hline & & Incorporation & 2.2 & 87 & 3.8 & 149 & 154 & 6.1 & 6.8 \\
\hline & & Surface application & 2.1 & 84 & 3.6 & 143 & 142 & 5.6 & 6.8 \\
\hline \multirow[t]{5}{*}{1993} & \multirow[t]{2}{*}{ Slurry } & Incorporation & 3.2 & 54 & 3.8 & 65 & 14 & 0.2 & n.d. \\
\hline & & Surface application & 3.3 & 79 & 3.9 & 92 & 12 & 0.3 & n.d. \\
\hline & \multirow[t]{3}{*}{ Peat manure } & Newly mixed & 2.4 & - & 5.0 & - & 173 & - & 6.3 \\
\hline & & Incorporation & 2.5 & 89 & 5.1 & 182 & 199 & 7.1 & n.d. \\
\hline & & Surface application & 2.6 & 94 & 5.9 & 209 & 214 & 7.6 & n.d. \\
\hline
\end{tabular}

n.d. $=$ not determined

The experimental field was treated annually, in June, with a herbicide. Barley was harvested in August. The moisture content of grain yield was determined by drying at $105^{\circ} \mathrm{C}$ overnight. Another sample was dried at $30^{\circ} \mathrm{C}$ for about one day, cleaned and its $\mathrm{N}$ concentration was determined by near infrared reflectance technique. Grain yields are reported as cleaned and corresponding to $15 \%$ moisture content. The apparent recovery of $\mathrm{N}$ was calculated by dividing the difference in $\mathrm{N}$ yield between fertilized and unfertilized plot by the amount of ammoniacal slurry $\mathrm{N}$ and total inorganic ferti- lizer $\mathrm{N}$ applied to the fertilized plot. Primary tillage was carried out in September or October by ploughing to 20-22 cm depth with a mouldboard plough (in two of the four replications) or as a stubble mulch tillage to $13-15 \mathrm{~cm}$ depth with a field cultivator (in the other two replications). The effect of the primary tillage method was only considered in the investigation of the residual effect of the treatments in 1994, that is not reported in this paper. In the earlier years, there were no marked differences in yield caused by the primary tillage method. 
Vol. 15 (2006): 124-137.

\section{Statistical analyses}

Analysis of variance was performed for the annual results of slurry and peat manure plots according to the design of the experiment with the GLM procedure of SAS statistical software version 6.12 (SAS Institute Inc. 1990). Some treatments were arranged as strips as described above, which was considered in determining the structure of the error terms (Table 3, Steel and Torrie 1981). The effects of application method and supplementary fertilization were analysed separately for slurry and peat manure because the arrangement of these treatments was different in slurry and peat manure plots. The effect of plain peat on grain yield was analysed with the pairwise t-test. Each peat plot that had not received supplementary fertilization was compared with the unfertilized plot of the same main plot, and each peat plot where supplementary fertilizer was applied was compared with the inorganic fertilizer plot of $40 \mathrm{~kg} \mathrm{~N} \mathrm{ha}^{-1}$ rate. The t-test was carried out separately for incorporated and surface applied peat. To investigate the effect of application method and irrigation in plain peat plots, the analysis of variance was carried out for the peat plots in the same way as for the peat manure plots. The reported effects in slurry, peat manure and peat plots are statistically significant $(\mathrm{P}<0.05)$, if not mentioned otherwise.

\section{Results}

For simplicity, only the extremes of soil moisture conditions are included in the presented results: figures show the grain yield and $\mathrm{N}$ recovery of unirrigated plots and plots that were irrigated both before sprouting and at normal time.

\section{Conservation of $\mathrm{N}$ in peat manure during storage}

The concentration of ammoniacal $\mathrm{N}$ and total $\mathrm{N}$ in peat manure in spring was close to that just after mixing of the slurry and peat (Table 2). Apparently, manure $\mathrm{N}$ was conserved well over winter and

Table 3. Factors, interactions and corresponding error terms of the statistical model used in the analysis of variance.

\begin{tabular}{ll}
\hline Factor or interaction & Error term \\
\hline $\begin{array}{l}\text { Slurry and peat manure } \\
\text { Irrigation }\end{array}$ & Block $\times$ Irrigation \\
Manure & Block $\times$ Manure \\
Irrigation $\times$ Manure & Block $\times$ Irrigation $\times$ Manure \\
Slurry & \\
Application & Block $\times$ Application \\
Irrigation $\times$ Application & Block $\times$ Irrigation $\times$ Application \\
Supplement, Irrigation $\times$ Supplement, & Block $\times$ Irrigation $\times$ Application $\times$ Supplement \\
Application $\times$ Supplement & \\
Peat manure & \\
Application, Irrigation $\times$ Application & Block $\times$ Irrigation $\times$ Application \\
Supplement & Block $\times$ Supplement \\
Irrigation $\times$ Supplement & Block $\times$ Irrigation $\times$ Supplement \\
Application $\times$ Supplement & Block $\times$ Irrigation $\times$ Application $\times$ Supplement \\
\hline
\end{tabular}


Mattila, P.K. Barley yield and $N$ recovery from manures

composting was not intense in a peat manure heap covered with straw and plastic sheets.

\section{Grain yield}

The average yield of barley grain was 5-15\% higher in peat manure plots than in slurry plots (Table 4). The difference was smallest and not significant in 1992, when drought noticeably lowered all yields (Fig. 2). The amount of ammoniacal $\mathrm{N}$ applied in manures, especially in slurry, in some cases differed considerably from the target level of $80 \mathrm{~kg} \mathrm{ha}^{-1}$ (Table 2). This was not directly reflected in differences in grain yield, however. The yields of slurry and peat manure plots were almost always lower than the yields obtained with inorganic fertilizer at the corresponding $\mathrm{N}$ rate of $80 \mathrm{~kg} \mathrm{ha}^{-1}$.
However, the difference between the manures and inorganic fertilizer was not tested statistically.

Incorporation of slurry increased barley yield by $14 \%$ in 1990 and by $11 \%$ in 1991, but with peat manure there was no clear difference between incorporation and surface application in these years (Table 4). In 1990, the difference between incorporation and surface application of slurry was only $5 \%$, on average, in the treatments where the plots were irrigated before sprouting, but without the early irrigation $22 \%$ higher yields were obtained with incorporated slurry. Surface applied peat manure even produced $11 \%$ higher yield than incorporated peat manure when irrigated before sprouting, but without the early irrigation application technique had no large effect. In 1992 and 1993, when precipitation in May was exceptionally low (Fig. 2), both slurry and peat manure were more

Table 4. Cleaned barley grain yield $\left(\mathrm{Mg} \mathrm{ha}^{-1}\right)$ in the years 1990-1993. Standard error of mean is expressed in italics.

\begin{tabular}{|c|c|c|c|c|c|c|c|c|c|c|c|c|c|c|c|c|}
\hline \multirow[t]{2}{*}{ Year } & \multicolumn{8}{|c|}{ Unirrigated } & \multicolumn{8}{|c|}{ Irrigated twice } \\
\hline & & \multicolumn{2}{|c|}{ Slurry } & \multicolumn{2}{|c|}{ Peat manure } & \multicolumn{3}{|c|}{ NPK } & & \multicolumn{2}{|c|}{ Slurry } & \multicolumn{2}{|c|}{ Peat manure } & I & \multicolumn{2}{|l|}{ NPK } \\
\hline \multirow[t]{5}{*}{1990} & INC & 1.99 & 0.05 & 2.29 & 0.10 & I & UNF & 0.97 & INC & 3.60 & 0.35 & 3.58 & 0.27 & I & UNF & 2.15 \\
\hline & INC SF & 2.95 & 0.16 & 2.99 & 0.13 & I & 40 & 2.15 & INC SF & 4.32 & 0.20 & 4.50 & 0.39 & I & 40 & 3.20 \\
\hline & SUR & 1.48 & 0.17 & 2.20 & 0.21 & I & 80 & 2.76 & SUR & 3.37 & 0.23 & 4.00 & 0.30 & I & 80 & 3.87 \\
\hline & SUR SF & 2.39 & 0.09 & 3.18 & 0.23 & I & 120 & 3.04 & SUR SF & 4.17 & 0.29 & 4.59 & 0.39 & I & 120 & 4.21 \\
\hline & & & & & & I & & & & & & & & I & & \\
\hline \multirow[t]{5}{*}{1991} & INC & 3.96 & 0.28 & 4.33 & 0.22 & I & UNF & 1.70 & INC & 4.24 & 0.24 & 4.50 & 0.19 & I & UNF & 2.12 \\
\hline & INC SF & 4.79 & 0.27 & 5.27 & 0.14 & I & 40 & 3.37 & INC SF & 5.36 & 0.10 & 5.48 & 0.14 & I & 40 & 3.83 \\
\hline & SUR & 3.34 & 0.47 & 4.05 & 0.21 & I & 80 & 4.30 & SUR & 3.59 & 0.38 & 4.47 & 0.33 & I & 80 & 5.07 \\
\hline & SUR SF & 4.40 & 0.33 & 5.29 & 0.14 & I & 120 & 4.92 & SUR SF & 4.97 & 0.33 & 5.42 & 0.20 & I & 120 & 5.56 \\
\hline & & & & & & I & & & & & & & & I & & \\
\hline \multirow[t]{5}{*}{1992} & INC & 1.65 & 0.06 & 1.52 & 0.17 & I & UNF & 0.64 & INC & 3.49 & 0.50 & 3.82 & 0.32 & I & UNF & 1.87 \\
\hline & INC SF & 2.22 & 0.13 & 2.08 & 0.13 & I & 40 & 1.63 & INC SF & 4.42 & 0.67 & 4.71 & 0.39 & I & 40 & 3.26 \\
\hline & SUR & 0.83 & 0.19 & 0.83 & 0.12 & I & 80 & 1.78 & SUR & 2.92 & 0.42 & 2.44 & 0.25 & I & 80 & 3.93 \\
\hline & SUR SF & 1.36 & 0.21 & 1.97 & 0.21 & I & 120 & 2.04 & SUR SF & 3.59 & 0.42 & 3.86 & 0.32 & I & 120 & 4.56 \\
\hline & & & & & & I & & & & & & & & I & & \\
\hline \multirow[t]{4}{*}{1993} & INC & 3.18 & 0.38 & 3.47 & 0.20 & I & UNF & 1.64 & INC & 3.32 & 0.38 & 4.24 & 0.15 & I & UNF & 2.08 \\
\hline & INC SF & 4.51 & 0.29 & 4.63 & 0.21 & I & 40 & 3.45 & INC SF & 5.09 & 0.33 & 5.64 & 0.08 & I & 40 & 3.96 \\
\hline & SUR & 2.09 & 0.40 & 2.60 & 0.39 & I & 80 & 4.32 & SUR & 3.11 & 0.13 & 4.00 & 0.18 & I & 80 & 5.20 \\
\hline & SUR SF & 3.62 & 0.33 & 4.23 & 0.41 & I & 120 & 4.85 & SUR SF & 4.97 & 0.21 & 5.50 & 0.07 & I & 120 & 6.09 \\
\hline
\end{tabular}

INC = incorporated, SUR = surface applied, SF = supplemented with NPK fertilizer $\left(40 \mathrm{~kg} \mathrm{~N} \mathrm{ha}^{-1}\right)$, NPK = inorganic NPK fertilizer $\left(40,80,120=\mathrm{N}\right.$ rate in $\left.\mathrm{kg} \mathrm{ha}^{-1}\right), \mathrm{UNF}=$ unfertilized. 
Vol. 15 (2006): 124-137.

effective when incorporated than when surface applied. The dry matter content of slurry was much higher in 1990 and 1991 than in 1992 and 1993 (Table 2), which may have resulted in slower infiltration of slurry into the soil and have added to the difference between the incorporation and surface application of slurry in the first two years.

Supplementary inorganic fertilization $(40 \mathrm{~kg}$ $\mathrm{N} \mathrm{ha}^{-1}$ ) raised barley yield significantly in all four years (Table 4), and the increase was greatest in 1992 and 1993 when the weather in May was dry. With inorganic fertilizer, the corresponding yield increase between the $\mathrm{N}$ rates of 80 and $120 \mathrm{~kg} \mathrm{ha}^{-1}$ was much smaller. Without supplementary fertilization, manure in most cases produced lower yield than the corresponding $80 \mathrm{~kg} \mathrm{ha}^{-1}$ of inorganic fertilizer N. Instead, when supplemented with $40 \mathrm{~kg} \mathrm{ha}^{-1}$ of inorganic fertilizer $\mathrm{N}$, manure sometimes produced even higher yield than the corresponding inorganic fertilizer $\mathrm{N}$ dose of $120 \mathrm{~kg} \mathrm{ha}^{-1}$. However, the effects of the manures and inorganic fertilizer were not compared statistically. Especially with peat manure, supplementary fertilization raised barley yield more with surface application than with incorporation (Table 4).

Plain peat was included in the experiment in 1990 and 1991 to investigate its effect without slurry addition. In 1990, when the spring was rather dry, peat increased yield relative to plots of corresponding inorganic fertilizer $\mathrm{N}$ level (0 or $40 \mathrm{~kg} \mathrm{ha}^{-1}$ ) without peat application (Table 5). Yield was higher with surface application of peat than with incorporation. As compared with 1990, the effect of peat was weaker in 1991 when there was more precipitation in May (Fig. 2). Peat increased yield in unirrigated plots, but not in irrigated ones.

All irrigation treatments increased grain yield in all years except 1991 (Table 4). In that year, precipitation in May and early June was heavier and more evenly distributed than in the other years (Fig. 2).

Each plot received the same treatments throughout the experiment. Thus, if there was a residual effect it may have affected barley growth in 1991-1993, but the possible effect appears to be weak. Results for any single year depended in the first place on the treatments and weather conditions of that year.

\section{Quality of grain yield}

The $\mathrm{N}$ concentration of grain yield varied between 1.6 and $2.6 \%$ of dry matter. The $\mathrm{N}$ concentration was higher in slurry plots than in peat manure plots in all years, but the difference was statistically significant only in 1992 and 1993. In all years except 1993, supplementary fertilization increased the $\mathrm{N}$ concentration. With inorganic fertilizer, grain $\mathrm{N}$ concentration appeared to increase with fertilizer $\mathrm{N}$ rate. In general, irrigation lowered the $\mathrm{N}$ concentration of grain yield and the effect was the stronger the later the irrigation was applied.

Table 5. Cleaned barley grain yield $\left(\mathrm{Mg} \mathrm{ha}^{-1}\right)$ in the years 1990 and 1991 of the plots where plain peat was applied. Standard error of mean is expressed in italics.

\begin{tabular}{|c|c|c|c|c|c|c|c|c|}
\hline \multirow[b]{3}{*}{ Incorporated } & \multicolumn{4}{|c|}{1990} & \multicolumn{4}{|c|}{1991} \\
\hline & \multicolumn{2}{|c|}{ Unirrigated } & \multicolumn{2}{|c|}{ Irrigated twice } & \multicolumn{2}{|c|}{ Unirrigated } & \multicolumn{2}{|c|}{ Irrigated twice } \\
\hline & 1.25 & 0.13 & 2.99 & 0.18 & 2.27 & 0.20 & 2.27 & 0.06 \\
\hline Incorporated, supplemented ${ }^{1)}$ & 2.44 & 0.06 & 4.07 & 0.28 & 3.80 & 0.13 & 4.10 & 0.15 \\
\hline Surface applied & 1.35 & 0.20 & 3.16 & 0.33 & 2.49 & 0.37 & 2.02 & 0.25 \\
\hline Surface applied, supplemented ${ }^{1)}$ & 2.67 & 0.08 & 4.27 & 0.28 & 4.06 & 0.22 & 3.71 & 0.25 \\
\hline Unfertilized & 0.97 & & 2.15 & & 1.70 & 2.12 & & \\
\hline NPK fertilizer ${ }^{1)}$ & 2.15 & & 3.20 & & 3.37 & 3.83 & & \\
\hline
\end{tabular}

${ }^{1)}$ Inorganic NPK fertilizer, $40 \mathrm{~kg} \mathrm{~N} \mathrm{ha-1}$ 
Mattila, P.K. Barley yield and $N$ recovery from manures

The moisture content of barley grain yield was $16-39 \%$, and the portion of clean yield was $92-$ $99 \%$. Incorporation and in most cases also supplementary fertilization resulted in lower moisture content and cleaner yield than was obtained with surface application or without supplementary fertilizer. When spring and early summer were dry, irrigation reduced moisture content and increased cleanness.

\section{Apparent recovery of ammoniacal manure $\mathrm{N}$ and total fertilizer $\mathrm{N}$}

There was no consistent difference in the apparent recovery of manure ammoniacal $\mathrm{N}$ between slurry and peat manure, because grain yield and its $\mathrm{N}$ concentration were inversely related. In 1990, the apparent recovery of ammoniacal $\mathrm{N}$ of peat manure was higher than that of slurry (Table 6), but in the other years there was no significant difference between the manures. In all years, apparent recovery of ammoniacal $\mathrm{N}$ was higher for incorporated slurry than for surface applied slurry. With peat manure the difference between incorporation and surface application was small in 1990 and 1991, but larger in 1993 and especially in the very dry year 1992 when incorporation resulted in a clearly higher recovery with peat manure as well as slurry. In 1990, irrigation before sprouting was highly beneficial for the recovery of $\mathrm{N}$ from surface applied manures, and especially for peat manure.

Table 6. Apparent recovery of manure ammoniacal $\mathrm{N}$ and inorganic fertilizer $\mathrm{N}$ in barley grain yield in the years 1990 1993 (\% of applied N). Standard error of mean is expressed in italics.

\begin{tabular}{|c|c|c|c|c|c|c|c|c|c|c|c|c|c|c|c|c|}
\hline \multirow[t]{2}{*}{ Year } & \multicolumn{8}{|c|}{ Unirrigated } & \multicolumn{8}{|c|}{ Irrigated twice } \\
\hline & & \multicolumn{2}{|c|}{ Slurry } & \multicolumn{2}{|c|}{ Peat manure } & I & \multicolumn{2}{|c|}{ NPK } & & \multicolumn{2}{|c|}{ Slurry } & \multicolumn{3}{|c|}{ Peat manure } & \multicolumn{2}{|l|}{ NPK } \\
\hline \multirow[t]{5}{*}{1990} & INC & 31 & 1.6 & 42 & 2.4 & I & 40 & 75 & INC & 45 & 2.9 & 46 & 8.9 & I & 40 & 67 \\
\hline & INC SF & 41 & 2.9 & 43 & 2.6 & I & 80 & 57 & INC SF & 45 & 4.7 & 50 & 8.0 & I & 80 & 55 \\
\hline & SUR & 18 & 5.1 & 37 & 6.0 & | & 120 & 44 & SUR & 44 & 7.2 & 55 & 9.7 & I & 120 & 44 \\
\hline & SUR SF & 33 & 1.3 & 45 & 4.3 & I & & & SUR SF & 47 & 4.8 & 49 & 6.7 & I & & \\
\hline & & & & & & I & & & & & & & & I & & \\
\hline \multirow[t]{5}{*}{1991} & INC & 40 & 3.4 & 51 & 6.5 & I & 40 & 64 & INC & 35 & 2.3 & 43 & 4.0 & I & 40 & 68 \\
\hline & INC SF & 42 & 1.1 & 50 & 3.1 & I & 80 & 59 & INC SF & 42 & 1.0 & 46 & 3.9 & I & 80 & 60 \\
\hline & SUR & 33 & 4.5 & 45 & 4.7 & I & 120 & 51 & SUR & 28 & 4.8 & 42 & 6.0 & I & 120 & 50 \\
\hline & SUR SF & 39 & 2.3 & 49 & 3.8 & I & & & SUR SF & 37 & 3.5 & 44 & 2.8 & I & & \\
\hline & & & & & & 1 & & & & & & & & 1 & & \\
\hline \multirow[t]{5}{*}{1992} & INC & 30 & 2.1 & 21 & 3.7 & I & 40 & 48 & INC & 42 & 9.7 & 38 & 6.6 & I & 40 & 57 \\
\hline & INC SF & 31 & 2.0 & 25 & 1.8 & I & 80 & 32 & INC SF & 45 & 8.4 & 42 & 3.6 & I & 80 & 49 \\
\hline & SUR & 4 & 2.5 & 5 & 1.6 & I & 120 & 27 & SUR & 21 & 5.2 & 13 & 5.5 & I & 120 & 46 \\
\hline & SUR SF & 10 & 1.9 & 21 & 2.6 & I & & & SUR SF & 24 & 3.4 & 28 & 2.9 & I & & \\
\hline & & & & & & I & & & & & & & & I & & \\
\hline \multirow[t]{4}{*}{1993} & INC & 50 & 6.9 & 36 & 2.3 & | & 40 & 64 & INC & 41 & 12.1 & 36 & 4.5 & I & 40 & 62 \\
\hline & INC SF & 54 & 3.0 & 41 & 1.4 & I & 80 & 59 & INC SF & 55 & 4.4 & 43 & 1.3 & I & 80 & 60 \\
\hline & SUR & 14 & 4.6 & 21 & 4.0 & I & 120 & 52 & SUR & 28 & 3.6 & 36 & 1.3 & I & 120 & 57 \\
\hline & SUR SF & 33 & 2.2 & 35 & 2.4 & I & & & SUR SF & 43 & 3.7 & 41 & 2.2 & I & & \\
\hline
\end{tabular}

INC = incorporated, SUR = surface applied, $\mathrm{SF}=$ supplemented with NPK fertilizer $\left(40 \mathrm{~kg} \mathrm{~N} \mathrm{ha}^{-1}\right)$, NPK = inorganic NPK fertilizer $\left(40,80,120=\mathrm{N}\right.$ rate in $\left.\mathrm{kg} \mathrm{ha}^{-1}\right)$. 
Vol. 15 (2006): 124-137.

The calculation of the apparent recovery of $\mathrm{N}$ was based on the difference of $\mathrm{N}$ yield between fertilized and unfertilized plots within the same irrigation treatment. Irrigation increased $\mathrm{N}$ uptake in both fertilized and unfertilized plots and, therefore, in many cases the increased uptake of applied $\mathrm{N}$ due to irrigation did not result in higher apparent $\mathrm{N}$ recovery.

The recovery of inorganic fertilizer $\mathrm{N}$ appeared to decrease with increasing application rate. In manure amended plots, however, supplementing the manures with inorganic fertilizer increased the combined apparent recovery of manure and fertilizer $\mathrm{N}$ in all years. Surface applied manures benefited from supplementation more than incorporated ones. The interaction between application method and supplementary fertilization was significant with slurry in all years and with peat manure in 1992 and 1993.

Theoretically, exhaustion of plant-available soil $\mathrm{N}$ in unfertilized plots could have lowered the $\mathrm{N}$ yields and, thereby, increased the apparent recovery of $\mathrm{N}$ applied in fertilized plots in the later years. However, this was not observed in the results. Instead, annual weather conditions seemed to determine the amount of mineralized $\mathrm{N}$ and barley yield of the unfertilized plots in the separate years.

\section{Discussion}

\section{Manure and application method}

The somewhat higher yields produced by peat manure compared with slurry may have been due to the ability of peat to adsorb ammoniacal $\mathrm{N}$ in plant-available form and improve soil moisture conditions. These properties are particularly important with surface application, which is supported by the findings of Al-Kanani et al. (1992), who observed that the addition of Sphagnum peat did not affect the fertilizer effect of pig slurry on barley in a pot experiment where manure was incorporated into the soil. Also in Hakkola's (1994) field experiment there was no significant difference in barley yield between incorporated peat manure and cattle slurry.

Soil moisture conditions had a large effect on barley growth and utilization of manure N. The small difference in yield and $\mathrm{N}$ recovery between incorporated and surface applied peat manure in 1990 and 1991 can be attributed to moderately good water availability in May and early June, which was enhanced by the peat. Similarly, the positive effect of plain peat on grain yield is presumably related to improved soil moisture conditions, because peat contained hardly any readily available $\mathrm{N}$ (Table 2). The moisture conserving effect of peat was stronger after surface application than after incorporation. In the dry springs of 1992 and 1993, however, peat manure cover did not retard moisture loss from the already dry soil and drought limited the availability of $\mathrm{N}$ from surface applied peat manure more than it did from incorporated manure. Consequently, higher yield and $\mathrm{N}$ recovery were achieved when peat manure was incorporated.

In agreement with earlier experiments (Kemppainen 1989, p. 202-219, Petersen 1996, Smith et al. 2000, Sørensen and Amato 2002), surface applied slurry had weaker $\mathrm{N}$ fertilization effect than slurry incorporated into the soil. Lindén et al. (1998) observed that the spring application method of pig slurry had a rather weak effect on spring barley yield and $\mathrm{N}$ recovery on a sandy soil, but incorporation appeared to enhance the effect of slurry in some cases. Larger infiltration of slurry into sandy soil than into clay soil (Bischoff 1984) may reduce the difference between surface application and incorporation on a sandy soil.

Consistently with Petersen's (1996) results, lower grain yield was usually associated with higher $\mathrm{N}$ concentration of the grain, when barley was fertilized with slurry or peat manure. High $\mathrm{N}$ concentration of the low yields shows that some $\mathrm{N}$ was available to the crop at later stages of growth even though the initial availability of ammoniacal manure $\mathrm{N}$ was low in these cases.

Higher moisture content and lower cleanness of barley grain yield in surface application plots than in plots with incorporation was apparently a 
Mattila, P.K. Barley yield and $N$ recovery from manures

consequence of poor availability of $\mathrm{N}$ in spring and early summer. Some of the $\mathrm{N}$ may have become available later during the summer delaying ripening. Enhanced $\mathrm{N}$ availability through incorporation or irrigation resulted in a visibly higher density of barley stand, which was likely to promote uniform ripening by restricting late tillering and weed growth. The moisture content of grain yield was thus lower and the yield cleaner.

In optimal conditions, the inorganic $\mathrm{N}$ of manure may be as effective as fertilizer $\mathrm{N}$, but usually it is not achieved (Kirchmann 1985, p. 62, Zebarth et al. 1996). The apparent recovery of manure ammoniacal $\mathrm{N}$ was in most cases lower than that of inorganic fertilizer $\mathrm{N}$, in accord with the results of earlier experiments (e.g. Sørensen and Amato 2002).

Ammonia volatilization lowers the recovery of manure $\mathrm{N}$ particularly when manure is not incorporated. Especially with surface applied manures, irrigation may have reduced $\mathrm{NH}_{3}$ loss (Sommer and Christensen 1990) and has increased the availability of manure $\mathrm{N}$ for barley. However, irrigation before sprouting was carried out two to five days after the surface application of manures and, thus, there was some time for $\mathrm{NH}_{3}$ volatilization. $\mathrm{NH}_{3}$ loss may have been relatively low also without irrigation, because tillage shortly before application reduces $\mathrm{NH}_{3}$ volatilization from slurry by promoting its infiltration into the soil (Sommer and Ersbøll 1994) and peat adsorbs $\mathrm{NH}_{3}$ in peat manure.

Other factors that decrease the availability of manure $\mathrm{N}$ for plants are fixation of ammoniacal $\mathrm{N}$ into clay minerals and immobilization of inorganic manure $\mathrm{N}$ into soil organic matter. Several earlier experiments have indicated initial immobilization of $\mathrm{N}$ during the first few weeks after manure application followed by remineralization (e.g. Flowers and Arnold 1983, Trehan and Wild 1993). Also fixed ammonium may be released (Trehan and Wild 1993). Immobilization may be high particularly if material with high $\mathrm{C} / \mathrm{N}$ ratio (e.g. straw) has been added to the manure (Kirchmann 1985, p. 61-62). Peat, however, decomposes slowly (Persson and Kirchmann 1994) and the ammoniacal N of peat manure is not immobilized to as large extent as the ammoniacal $\mathrm{N}$ of straw manure, for ex- ample. In the experiments of Gagnon et al. (1998), straw manure did not contribute to soil inorganic $\mathrm{N}$, whereas peat manure increased soil $\mathrm{N}$ early in the growing season. The increase was mainly from the inorganic $\mathrm{N}$ of peat manure, whereas the organic fraction had a negligible effect. These results confirm that the organic matter of peat is recalcitrant to microbial decomposition.

The location of manure and its $\mathrm{N}$ in the soil may have a marked effect on $\mathrm{N}$ availability especially in dry conditions. A large portion of the ammoniacal $\mathrm{N}$ of surface applied manure that is not volatilized as $\mathrm{NH}_{3}$ may remain in the manure or in the very top of the soil (Beauchamp et al. 1982), where it is unavailable to roots. The $\mathrm{N}$ of inorganic fertilizer placed to $8-\mathrm{cm}$ depth tends to be better available for plants than the $\mathrm{N}$ of manure incorporated to $0-5-\mathrm{cm}$ depth because there is usually more moisture deeper in the soil. After incorporation by harrowing, manure is not totally covered by the soil and some $\mathrm{NH}_{3}$ volatilization is possible (Sommer and Christensen 1990), which further reduces the amount of plant available N. In a pot experiment where manures and fertilizers were mixed into the soil in a similar way, Kemppainen (1987) observed that the ammoniacal $\mathrm{N}$ of dairy cattle peat manure was as effective as the $\mathrm{N}$ of inorganic fertilizer. During germination, however, incorporated manure may have a stronger effect than placed fertilizer because the manure is situated closer to the seed. Applying fertilizer in close contact with seed has proven beneficial for the early growth of spring cereals when there is sufficient moisture in the soil (Kleemola et al. 1998). When incorporated into seedbed, manure may have a similar, although weaker, effect.

\section{Supplementary $\mathrm{N}$ fertilization}

Boosting the early growth with fertilizer $\mathrm{N}$ enhances the ability of the crop to utilize manure $\mathrm{N}$ at later growth stages, when the manure adds to the amount of available N. Enhanced N availability through supplementary fertilization also results in a higher density of crop stand and, consequently, lower moisture content and higher cleanness of 
Vol. 15 (2006): 124-137.

grain yield. Kemppainen (1989, p. 212-213) and Petersen (1996) obtained increased spring barley grain yield with higher $\mathrm{N}$ concentration and lower moisture content when slurry was supplemented with inorganic fertilizer $\mathrm{N}$, but, unlike in the results reported here, the apparent recovery of $\mathrm{N}$ was decreased slightly. The weaker effect of supplementary fertilizer on apparent recovery in their experiments may have been a consequence of more precipitation in May in Kemppainen's experiment and a more favourable soil type in Petersen's experiment, which enhanced the utilization of manure N. Furthermore, in Petersen's experiment supplementary fertilizer was applied as surface dressing between sowing and tillering, whereas in the experiment reported here fertilizer was placed at sowing, a method that is likely to increase and hasten the availability of fertilizer $\mathrm{N}$ for the crop.

Combined use of manure and nitrate-containing fertilizer may increase nitrous oxide emissions from the soil (Stevens and Laughlin 2001) and the organic matter of manure may enhance immobilization of fertilizer N (Rees and Castle 2002). However, in the experiment reported here, placed fertilizer was not in direct contact with manure, which reduces the possible negative effects.

\section{Organic manure $\mathrm{N}$}

The $\mathrm{N}$ of manure organic matter did not have a clear effect on barley yield either in the year of application nor through a residual effect in the following years. Earlier experiments, too, have shown in most cases that the short-term fertilizer effect of manure strongly depends on its concentration of inorganic N (e.g. Beauchamp 1987, Zebarth et al. 1996), which usually consists mainly of ammoniacal $\mathrm{N}$. The rate of $\mathrm{N}$ release from the organic matter of manure is low and does not differ much from the release of $\mathrm{N}$ from soil organic matter (Beauchamp 1987). Organically bound $\mathrm{N}$ of manure may contribute to plant available $\mathrm{N}$ in some cases, but its effect is uncertain and difficult to predict (Stockdale and Rees 1995). In conditions favourable for mineralization, however, Kirchmann (1985, p. 51) observed that the uptake of $\mathrm{N}$ from solid manure was clearly higher than the content of inorganic $\mathrm{N}$ in the manure. Repeated manure applications over several years may lead to gradual increase in mineralizable soil N (Chang and Janzen 1996).

\section{Conclusions}

Peat manure gave somewhat higher barley grain yields than slurry, especially when application was made to the soil surface. However, both slurry and peat manure should be incorporated to improve and ensure the utilization of manure N. Soil moisture deficit in spring and early summer limited the availability of manure $\mathrm{N}$ and lowered barley yield and its quality. Part of the manure $\mathrm{N}$ that was not available in the early growing season was apparently taken up by the crop later. Consequently, lower yields in most cases had higher $\mathrm{N}$ concentrations, which made differences in the recovery of manure $\mathrm{N}$ smaller than the differences in grain yield.

Sufficient supply of $\mathrm{N}$ at the early stages of growth is important for the formation of barley grain yield. Supplementation of manures with inorganic fertilizer $\mathrm{N}$ increased both yield and $\mathrm{N}$ recovery, which indicates relatively low availability of manure $\mathrm{N}$ in the early part of the growing season. Irrespective of the type of manure, supplementary $\mathrm{N}$ fertilization is recommended especially in dry conditions and when the demand for plantavailable $\mathrm{N}$ is not met with a manure application rate that supplies sufficient amount of phosphorus.

Acknowledgements. The author dedicates this article to the late Professor Paavo Elonen, who designed the experiment reported here and supervised its field work. Technical assistance of the staff of Soils and Environment unit of MTT Agrifood Research Finland is gratefully acknowledged. The study was financially supported by the Finnish Ministry of Agriculture and Forestry and Vapo Oy. 


\title{
AGRICULTURAL AND FOOD SCIENCE
}

\author{
Mattila, P.K. Barley yield and N recovery from manures
}

\section{References}

Alakukku, L. \& Elonen, P. 1995. Cumulative compaction of a clay loam soil by annual repeated field traffic in autumn. Agricultural Science in Finland 4: 445-461.

Al-Kanani, T., Akochi, E., MacKenzie, A.F., Alli, I. \& Barrington, S. 1992. Organic and inorganic amendments to reduce ammonia losses from liquid hog manure. Journal of Environmental Quality 21: 709-715.

Araji, A.A., Abdo, Z.O. \& Joyce, P. 2001. Efficient use of animal manure on cropland - economic analysis. Bioresource Technology 79: 179-191.

Beauchamp, E.G. 1987. Corn response to residual $\mathrm{N}$ from urea and manures applied in previous years. Canadian Journal of Soil Science 67: 931-942.

Beauchamp, E.G., Kidd, G.E. \& Thurtell, G. 1982. Ammonia volatilization from liquid dairy cattle manure in the field. Canadian Journal of Soil Science 62: 11-19.

Bischoff, K. 1984. Infiltration von Rinder- und Schweinegülle auf verschiedenen Substraten. (Infiltration of cattle and pig slurry on various materials.) Archiv für Ackerund Pflanzenbau und Bodenkunde 28: 659-664. (in German)

Chang, C. \& Janzen, H.H. 1996. Long-term fate of nitrogen from annual feedlot manure applications. Journal of Environmental Quality 25: 785-790.

Drebs, A., Nordlund, A., Karlsson, P., Helminen, J. \& Rissanen, P. 2002. Climatological statistics of Finland 19712000. Climatic statistics of Finland 2002:1. Helsinki: Finnish Meteorological Institute. 98 p.

Flowers, T.H. \& Arnold, P.W. 1983. Immobilization and mineralization of nitrogen in soils incubated with pig slurry or ammonium sulphate. Soil Biology and Biochemistry 15: 329-335.

FMI 1991-1994. Meteorological yearbook of Finland 19901993. Helsinki: Finnish Meteorological Institute.

Gagnon, B., Simard, R.R., Goulet, M., Robitaille, R. \& Rioux, R. 1998. Soil nitrogen and moisture as influenced by composts and inorganic fertilizer rate. Canadian Journal of Soil Science 78: 207-215.

Galloway, J.N., Aber, J.D., Erisman, J.W., Seitzinger, S.P., Howarth, R.W., Cowling, E.B. \& Cosby, B.J. 1998. The nitrogen cascade. BioScience 53: 341-356.

Hakkola, H. 1994. Turpeeseen sekoitetun naudanlietelannan lannoitusvaikutus ja varastoinnin aikaiset ravinnehävikit. Summary: The fertilization effect of peat manure and nutrient losses during storage. Tiedote 3/94. Jokioinen: Maatalouden tutkimuskeskus. 20 p. (in Finnish)

Huijsmans, J., Verwijs, B., Rodhe, L. \& Smith, K. 2004. Costs of emission-reducing manure application. Bioresource Technology 93: 11-19.

Kemppainen, E. 1987. Ammonia binding capacity of peat, straw, sawdust and cutter shavings. Annales Agriculturae Fenniae 26: 89-94.

Kemppainen, E. 1989. Nutrient content and fertilizer value of livestock manure with special reference to cow manure. Annales Agriculturae Fenniae 28: 163-284.

Kemppainen, E. 1995. Leaching and uptake of nitrogen and phosphorus from cow slurry and fox manure in a lysimeter trial. Agricultural Science in Finland 4: 363-375.
Kirchmann, H. 1985. Losses, plant uptake and utilisation of manure nitrogen during a production cycle. Acta Agriculturae Scandinavica, Supplementum 24. 77 p.

Kleemola, J., Järvi, A. \& Kauppila, R. 1998. Placing nutrients with seed. Kungliga Skogs- och Lantbruksakademiens Tidskrift 137: 93-98.

Lindén, B., Carlgren, K. \& Svensson, L. 1998. Kväveutnyttjande på en sandjord i Halland vid olika sätt att sprida svinflytgödsel till stråsäd. Summary: Nitrogen utilization on a sandy soil after application of pig slurry to cereal crops with different techniques. Institutionen för markvetenskap. Avdelningen för växtnäringslära. Rapport 199. Uppsala: Sveriges Lantbruksuniversitet. 31 p. (in Swedish)

Persson, J. \& Kirchmann, H. 1994. Carbon and nitrogen in arable soils as affected by supply of $\mathrm{N}$ fertilizers and organic manures. Agriculture, Ecosystems \& Environment 51: 249-255.

Petersen, J. 1996. Fertilization of spring barley by combination of pig slurry and mineral nitrogen fertilizer. Journal of Agricultural Science, Cambridge 127: 151-159.

Puustjärvi, V. 1956. On the cation exchange capasity of peats and on the factors of influence upon its formation. Acta Agriculturae Scandinavica 6: 410-449.

Puustjärvi, V. 1976. Micro- and macrostructure of Sphagnum moss peat from the standpoint of its water economy. Peat and plant yearbook 1973-75: 5-10.

Rees, R. \& Castle, K. 2002. Nitrogen recovery in soils amended with organic manures combined with inorganic fertilisers. Agronomie 22: 739-746.

Russel, J.C. 1939. The effect of surface cover on soil moisture losses by evaporation. Soil Science Society of America Proceedings 4: 65-70.

SAS Institute Inc. 1990. SAS/STAT User's guide, Version 6, Fourth edition. Volume 2. Cary, North Carolina, SAS Institute Inc. $846 \mathrm{p}$.

Smith, K.A., Jackson, D.R., Misselbrook, T.H., Pain, B.F. \& Johnson, R.A. 2000. Reduction of ammonia emission by slurry application techniques. Journal of Agricultural Engineering Research 77: 277-287.

Sommer, S.G. \& Christensen, B.T. 1990. Ammoniakfordampning fra fast husdyrgødning samt ubehandlet, afgasset og filteret gylle efter overfladeudbringning, nedfældning, nedharvning og vanding. Summary: Ammonia volatilization from solid manure and raw, fermented and separated slurry after surface application, injection, incorporation into the soil and irrigation. Tidsskrift for Planteavl 94: 407-417. (in Danish)

Sommer, S.G. \& Ersbøll, S.K. 1994. Soil tillage effects on ammonia emission from surface-applied or injected animal slurry. Journal of Environmental Quality 23: 493-498.

Sørensen, P. \& Amato, M. 2002. Remineralisation and residual effects of $\mathrm{N}$ after application of pig slurry to soil. European Journal of Agronomy 16: 81-95.

Steel, R.G.D. \& Torrie, J.H. 1981. Principles and procedures of statistics. 2nd ed. Singapore: McGraw-Hill. $633 \mathrm{p}$.

Stevens, R.J. \& Laughlin, R.J. 2001. Cattle slurry affects nitrous oxide and dinitrogen emissions from fertilizer nitrate. Soil Science Society of America Journal 65: 1307-1314. 
Vol. 15 (2006): 124-137.

Stockdale, E.A. \& Rees, R.M. 1995. Release of nitrogen from plant and animal residues and consequent plant uptake efficiency. Biological Agriculture and Horticulture 11:229-245.

Trehan, S.P. \& Wild, A. 1993. Effects of an organic manure on the transformations of ammonium nitrogen in planted and unplanted soil. Plant and Soil 151: 287-294.

Turtola, E. \& Kemppainen, E. 1998. Nitrogen and phosphorus losses in surface runoff and drainage water after application of slurry and mineral fertilizer to perennial grass ley. Agricultural and Food Science in Finland 7: 569-581.

van der Hoek, K.W. 1998. Nitrogen efficiency in global animal production. Environmental Pollution 102, Supplement 1: 127-132.

Zebarth, B.J., Paul, J.W., Schmidt, O. \& McDougall, R. 1996. Influence of the time and rate of liquid-manure application on yield and nitrogen utilization of silage corn in south coastal British Columbia. Canadian Journal of Soil Science 76: 153-164.

\title{
SELOSTUS
}

\section{Turvelannalla tai sian lietelannalla lannoitetun ohran sato ja typen hyväksikäyttö}

\author{
Pasi K. Mattila \\ Helsingin yliopisto
}

Vähän maatunutta rahkaturvetta on perinteisesti käytetty kuivikkeena, koska se sitoo tehokkaasti lannan nestettä ja ammoniakkia. Uudempi tapa hyödyntää turvetta on lietelannan imeyttäminen turpeeseen silloin, kun lantavarasto on liian pieni koko talven lantamäärälle.

Tässä nelivuotisessa hiuesavimaalla tehdyssä kenttäkokeessa sian lietelantaa käytettiin ohran typpilannoitteena sellaisenaan tai rahkaturpeeseen imeytettynä määrä, joka sisälsi liukoista typpeä 54-106 kg ha-1. Lannat levitettiin keväällä joko ennen kylvöä, jolloin ne mullattiin äestämällä, tai kylvön jälkeen ilman multausta.

Turvelanta tuotti 5-15\% suuremman ohrasadon kuin lietelanta. Satoero oli suurin, kun lannat oli levitetty kylvön jälkeen ilman multausta. Vaikka multaaminen oli tärkeämpää lietelannalla, myös turvelanta on syytä mullata lannoitusvaikutuksen parantamiseksi. Kevään ja alkukesän kuivuus heikensi lannan typen hyväksikäyttöä, mikä alensi satoa. Ohra otti osan keväällä käyttämättä jääneestä typestä myöhemmin kesällä, minkä vuoksi sadon jäädessä alhaiseksi sen typpipitoisuus oli usein vastaavasti korkeampi. Näin ollen turvelannan ja lietelannan väliset erot typenotossa olivat pienemmät kuin jyväsadossa.

Turvelannan ja lietelannan täydentäminen kylvölannoituksena annettavalla väkilannoitetypellä lisäsi ohrasatoa keskimäärin $37 \%$ ja paransi myös typen hyväksikäyttöä, mikä viittaa lantojen typen melko huonoon käyttökelpoisuuteen erityisesti kuivissa olosuhteissa. Sekä lietelannan että turvelannan täydennyslannoitus on suositeltavaa kevätviljojen riittävän typensaannin varmistamiseksi kasvukauden alussa. 